\title{
PENGEMBANGAN BUKU CERITA BERBASIS PENDIDIKAN KARAKTER UNTUK MENINGKATKAN KREATIVITAS AUD
}

\author{
Dian Miranda \\ Dosen Prodi PG PAUD FKIP Untan, Pontianak \\ Email: dianmiranda84@gmail.com
}

\begin{abstract}
Anak merupakan pembelajar yang penuh kejujuran dalam mengekspresikan perasaan dan imajinasinya. Terkait dengan imajinasi, pada dasarnya semua anak kreatif dimana menurut George \& Zhou (dalam Ashkanasy \& Rowe, 2008) kreativitas adalah suatu produk ide atau solusi yang bersifat baru dan berguna. Menurut munandar (2002) salah satu manfaat kreativitas ilah dapat meningkatkan kulitas hidup dan memecahkan masalah dari berbagai sudut pandang, oleh sebab itu kreativitas penting untuk diasah sejak dini, agar menjadi karakter yang melekat dalam diri anak. Namun perlu difahami bahwa kreativitas tidak hanya terkait dengan kebaruan, tetapi juga harus berguna. Oleh sebab itu, kreativititas tidak boleh semaunya dan harus dibatasi dengan kemampuan memilih hal yang baik dan buruk, bermanfaat atau tidak bermanfaat, atau bahkan berdampak negatif. Oleh sebab itu anak perlu untuk diarahkan mengenai cara mengekspresikan perasaan dan imajinasinya dengan benar sesuai dengan nilai dan norma yang diterima di masyarakat maupun agama. Dalam rangka upaya meningkatkan kemampuan kreativitas dan menanamkan nilai karakter anak, maka penelitian ini berusaha untuk merancang dan membuat sebuah media pembelajaran yang sesuai bagi anak yaitu sebuah buku cerita bergambar bermuatan pendidikan karakter dan juga dapat meningkatkan kreativitas anak. Metode yang digunakan dalam penelitian ini adalah metode research and development (R\&D) dengan model prosedural, yaitu model yang bersifat deskriptif, yaitu menggariskan langkah-langkah yang harus diikuti untuk menghasilkan produk. Hasil yang didapat dari penelitian ini ialah buku cerita bergambar dinilai baik sebagai media penanaman karakter religius, toleransi, bersahabat, peduli sosial, disiplin, dan cinta damai serta baik digunakan sebagai media pengembang kreativitas anak usia dini khususnya anak usia 5-6 tahun.
\end{abstract}

\section{Key Word: Kreativtas, Pendidikan Karakter, Buku Cerita Bergambar}

\section{PENDAHULUAN}

Di era globalisasi saat ini yang didominasi oleh kemajuan ilmu pengetahuan dan teknologi membutuhkan individu-individu kreatif dan produktif serta memiliki kemampuan daya saing yang tinggi dan tangguh. Daya saing yang tinggi dan tangguh dapat terwujud jika anak didik memiliki kreativitas, kemandirian dan kemampuan menyesuaikan diri terhadap perubahanperubahan yang terjadi pada berbagai bidang kehidupan di masyarakat.

Pada dasarnya setiap manusia mempunyai potensi keatif. Hanya saja dalam perjalanan hidupnya ada yang mendapatkan kesempatan untuk mengembangkan potensi kreatifnya, ada pula yang kehilangan potensi kreatifnya karena tidak mendapat kesempatan ataupun tidak menemukan lingkungan yang memfasilitasi berkembangnya potensi kreatif $\mathrm{t}$

tersebut. Oleh karena itu kreatifitas perlu dirangsang perkembangannya sejak masa kanak-kanak.

Anak-anak pada dasarnya adalah individu yang kreatif. Mereka memiliki ciriciri yang oleh para ahli sering digolongkan sebagai ciri-ciri individu yang kreatif. Misalnya, rasa ingin tahu yang besar, sering bertanya, imajinasi yang tinggi, minat yang banyak, tidak takut salah, berani menghadapi resiko, bebas dalam berpikir, senang akan halhal yang baru, dan sebagainya. Dalam hal ini, orangtua dan guru perlu bekerja sama dan memahami kreatifitas anak-anak dengan bersikap luwes dan kreatif pula. 
Menurut Suratno (2005), anak kreatif dan cerdas tidak terbentuk dengan sendirinya melainkan perlu pengarahan, salah satunya dengan memberi kegiatan yang dapat mengembangkan kreativitas anak. Kreatifitas yang dimilik anak seharusnya mendapatkan perhatian, bimbingan serta stimulasi yang tepat agar dapat berkembang dengan optimal. Dengan demikian kita tidak boleh membiarkan pendidikan pada anak yang hanya menonjolkan kemampuan akademik saja seperti kemampuan membaca dan berhitung. Tetapi juga harus mengembangkan kreativitas serta menanamkan nilai-nilai karekter untuk pembentukan pribadi anak.

Rachmawati dan Kurniati (2010) menulisakan, selain bermanfaat baik bagi pengembangan diri, kreativitas juga merupakan salah satu kebutuhan pokok manusia, yaitu kebutuhan akan perwujudan diri. Dengan kreativitas anak dapat mengekspresikan dirinya, oleh sebab itu kretivitas perlu dibatasi dengan perkembangan nilai dan moral yang baik, agar anak dapat mewujudkan diri dengan benar melalui kreativitasnya.

Kreativitas didefinisikan secara berbeda-beda oleh para pakar berdasarkan sudut pandang masing-masing sehingga menghasilkan berbagai definisi kreativitas dengan penekanan yang berbeda-beda. Baron (dalam Utami Munandar, 2002) mendefinisikan bahwa kreativitas adalah kemampuan untuk menciptakan sesuatu yang baru. Sesuatu yang baru di sini bukan berarti harus sama sekali baru, tetapi dapat juga sebagai kombinasi dari unsure-unsur yang telah ada sebelumnya.

Konsep dan bentuk kreativitas AUD dan orang dewasa sangat berbeda. Kreatif dalam pengertian orang dewasa berarti keberadaan keahlian (expertise), keterampilan (skills), dan motivasi dalam diri (intrinsic task motivation). Orang dewasa yang kreatif diindikasikan sebagai individu yang memiliki keterampilan teknik prima, berkemampuan seni, dan memiliki bakat. Mereka juga memiliki gaya karya yang mempesona, keterbukaan ide yang mengagumkan, dan konsentrasi serta ketekunan yang luar biasa. Sehingga orang dewasa yang kreatif akan tercermin dari karya-karya dan ide-ide yang berbeda dan sebagian besar menjadi fenomenal.

Berbeda dengan orang dewasa, kreativitas anak dikoridori oleh keunikan gagasan dan tumbuhnya imajinasi serta fantasi. Anak-anak yang kreatif sensitif terhadap stimulasi. Mereka juga tidak dibatasi oleh frame-frame apapun. Artinya, mereka memiliki kebebasan dan keleluasan beraktivitas. Anak kreatif juga cenderung memiliki keasyikan dalam aktivitas. Kreativitas AUD juga ditandai dengan kemampuan membentuk imaji mental, konsep berbagai hal yang tidak hadir di hadapannya. AUD juga memiliki fantasi, imajinasi untuk membentuk konsep yang mirip dengan dunia nyata (Isenberg \& Jalongo, 1993).

Kreativitas anak muncul karena fitrahnya sebagai manusia yang berfikir. Anak menjadi kreatif karena mereka membutuhkan pemuasan dorongan emosi. Namun yang paling penting, kreativitas anak muncul karena anak perlu strategi untuk membangun konsep dan memecahkan masalah sesuai tingkat intelektualnya. Kreativitas muncul dari kemampuan berpikir divergen, lateral, multiarah. Pada teori belahan otak, kreativitas bersumber pada aktivitas hemisfer kanan. Dimana kemampuan berpikir divergen memiliki ciri-ciri generatif, eksploratif, tak terprediksi (unpredictable), dan multijawab. Meskipun demikian, proses terjadinya kreativitas juga melibatkan kemampuan berpikir konvergen. Oleh karena pada anak proses lateralisasi tengah terjadi, maka stimulasi pada belahan otak kanan menjadi sangat esensial dan fundamental.

Seorang anak dapat dikatakan kreatif ketika ia telah memenuhi syarat fluency 
dan flexibility dalam menemukan pemecahan atas sebuah permasalahan. Anak tentu saja melakukan fluency dengan memunculkan berbagai ide alternatif. Lebih lanjut anak akan mempertimbangkan berbagai hal untuk memilih solusi terbaik. Ketika anak menginginkan sesuatu, maka ia membutuhkan fluency sebagai preparation atau brainstorming. Anak kemudian melakukan berbagai pemikiran dan pertimbangan, bagaimana agar yang dilakukannya tersebut berhasil. Ia akan memilih salah satu alternative solusi yang ada dalam pikirannya. Anak melakukan flexibility karena konteks mulai berbicara. Ternyata, terdapat halangan dalam pelaksanaannya. Jika kemudian AUD itu berhasil menyelesaikan masalahnya, maka ia disebut kreatif. Tidak peduli jika solusi akhirnya diilhami oleh pengalaman orang lain. Dalam hal ini, originalitas tidak menjadi faktor utama kreativitas anak.

Paul Torrance dari Universitas Georgia dalam Suratno (2005) menyebutkan karakteristik tindakan kreatif anak adalah sebagai berikut :

a. Anak kreatif belajar dengan cara-cara yang kreatif,

Dalam proses pembelajaran seharusnya memberikan kesempatan pada anak untuk bereksperimen dan bereksplorasi sehingga anak memperoleh pengalaman yang berkesan dan menjadikan apa yang dipelajari anak lebih lama di ingat. Melalui eksperimen, eksplorasi, manipulasi dan permainan mereka sering mengajukan pertanyaan, membuat tebakan, dan kemudian mereka menemukan, kadangkala cepat dan emosional, sementara pada saat yang lain secara diam-diam saja. Dengan metode cerita bergambar kreativitas dapat dikembangkan karena anak akan sering mengajukan pertanyaan, membuat tebakan sesuai dengan ciri anak kreatif di atas. b. Anak kreatif memiliki rentang perhatian yang panjang terhadap hal yang membutuhkan usaha kreatif,

Anak kreatif memiliki rentang perhatian 15 menit lebih lama bahkan lebih dalam hal mengeksplorasi, bereskperimen, memanipulasi dan memainkan alat permainanya. Hal ini menunjukan anak yang kreatif tidak mudah bosan seperti halnya anak yang kurang kreatif. Melalui bercerita guru dapat mengidentifikasi anak yang kreatif maupun tidak kreatif yakni dilihat dari rentang perhatiannya dalam mendengarkan cerita. Kegiatan cerita bergambar dapat meningkatkan rentang perhatian anak karena gambar yang menarik membuat anak lebih fokus perhatiannya.

c. Anak kreatif memiliki kemampuan mengorganisasikan yang menakjubkan,

Anak kreatif adalah anak yang pikirannya berdaya dengan demikian anak kreatif sering merasa lebih dari pada anak yang lain. Bentuk kelebihan anak kreatif ditunjukan dengan peran mereka dalam kelompok bermain.

Anak kreatif muncul sebagai pemimpin bagi kelompoknya karena itu anak kreatif pada umumnya mampu mengorganisasikan teman-temannya secara menakjubkan. Jika anak mampu mengorganisasikan temantemannya maka anak akan memiliki kepercayan diri yang luar biasa. Melalui cerita bergambar anak belajar mengaitkan ide dan gagasan sebagai bekal untuk melatih kepercayaan diri anak karena jika anak berhasil mengaitkan ide atau gagasan maka lahitlah karya-karya yang original sehingga kepercayaan diri anak akan muncul dan secara tidak langsung anak termotivasi untuk mengekspresikannya didepan teman-temannya.

Anak kreatif dapat kembali kepada sesuatu yang sudah dikenalnya dan melihat dari cara yang berbeda, 
Anak kreatif merupakan anak yang suka belajar untuk memperoleh pengalaman. Anak tidak lekas bosan untuk mendapatkan pengalaman yang sama berkali-kali. Jika pengalaman pertama diperoleh mereka akan mencoba dengan cara lain sehingga diperoleh pengalaman baru. Melalui cerita bergambar anak dapat menceritakan kembali cerita yang disampaikan, dengan demikian anak telah mampu menghasilkan sesuatu yang baru dan original sesuai kemampuannya.

d. Anak kreatif belajar banyak melalui fantasi, dan memecahkan permasalahan dengan menggunakan pengalamannya,

Anak kreatif akan selalu haus dengan pengalaman baru. Pengalaman yang berkesan akan diperoleh secara langsung melalui eksperimen yang dilakukan. Anak harus diberikan banyak bekal pengalamannya melalui eksperimennya sendiri baik melalui kesenian, musik, drama kreatif atau cerita, maupun menggunakan bahasa yang mengekspresikan kelucuan, suasana atau atmosfir persoalan yang bebas dan dapat diterima oleh anak. Cerita bergambar dapat mengasah imajinasi dan fantasi anak, fantasi tersebut dapat diasah melalui alur cerita dan gambar yang ditampilkan. Misalnya apabila guru bercerita dengan setting lapangan, rumah sakit, anak-anak akan mempunyai persepsi dalam fantasinya masing-masing. Dengan fantasi tersebut, maka akan lebih meningkatkan kreativitas anak.

e. Anak kreatif menikmati permainan dengan kata-kata dan tempat sebagai pencerita yang alami.

Anak kreatif suka bercerita, bahkan kadang-kadang bercerita tidak habishabisnya sehingga sering dicap sebagai anak cerewet. Pada hal melalui aktivitasnya itu anak akan mengembangkan lebih lanjut fantasifantasinya, khayalan-khayalan imajinatifnya sehingga akan memperkuat kekreatifan anak. Melalui cerita bergambar anak akan sering mendapatkan kosakata baru, dengan kosakata yang diperolehnya tersebut akan dapat menjadi bekal anak sebagai pencerita yang alami.

Selain Torrance, munandar (1992) juga menjelaskan ciri-ciri kreativitas sebagai berikut:

Ciri-ciri yang berhubungan dengan kemampuan berpikir kreatif atau kognitif (aptitude) antara lain :

Keterampilan berpikir lancar, yaitu mencetuskan banyak gagasan, jawaban, penyelesaian masalah, pertanyaan, memberikan banyak cara atau saran untuk melakukan berbagai hal serta selalu memikirkan lebih dari satu jawaban.

Keterampilan berpikir luwes atau fleksibel, yaitu menghasilkan gagasan, jawaban atau pertanyaan yang bervariasi, dapat melihat suatu masalah dari sudut pandang yang berbeda-beda, mencari banyak alternatif atau arah yang berbedabeda, serta mampu mengubah cara pendekatan atau cara pemikiran.

Keterampilan berpikir orisinal, yaitu mampu melahirkan ungkapan yang baru dan unik, memikirkan cara yang tidak lazim untuk mengungkapkan diri, serta mampu membuat kombinasikombinasi yang lazim dari bagian-bagian atau unsurunsur.

Keterampilan memerinci atau mengelaborasi, yaitu mampu memperkaya dan mengembangkan suatu gagasan atau produk, dan menambahkan atau memerinci secara detail dari suatu obyek gagasan, atau situasi sehingga menjadi lebih menarik.

Keterampilan menilai, yaitu menentukan patokan penilaian sendiri dan penentuan apakah suatu pertanyaan benar, suatu rencana sehat, atau suatu tindakan bijaksana, mampu mengambil keputusan terhadap situasi yang terbuka, serta tidak 
hanya mencetuskan gagasan tetapi juga melaksanakannya.

Ciri-ciri yang menyangkut sikap dan perasaan seseorang atau afektif (non aptitude) antara lain adalah :

1) Upaya Rasa ingin tahu, meliputi suatu dorongan untuk mengetahui lebih banyak, mengajukan banyak pertanyaan, selalu memperhatikan orang lain, obyek dan situasi serta peka dalam pengamatan dan ingin mengetahui atau meneliti.

2) Bersifat imajinatif, meliputi kemampuan untuk memperagakan atau membayangkan hal-hal yang tidak atau belum pernah terjadi, dan menggunakan khayalan tetapi mengetahui perbedaan antara khayalan dan kenyataan.

3) Merasa tertantang oleh kemajemukan, meliputi dorongan untuk mengatasi masalah-masalah yang sulit, merasa tertantang oleh situasi-situasi yang rumit, serta lebih tertarik pada tugas-tugas yang sulit.

4) Sikap berani mengambil resiko, meliputi keberanian memberikan jawaban meskipun belum tentu benar, tidak takut gagal atau mendapat kritik, serta tidak menjadi raguragu karena ketidakjelasan hal-hal yang tidak konvensional, atau yang kurang berstruktur.

5) Sikap menghargai, meliputi tindakan dapat menghargai bimbingan dan pengarahan dalam hidup, serta menghargai kemampuan dan bakat-bakat sendiri yang sedang berkembang.

Pendidikan karakter bukan sekedar membiasakan anak berperilaku baik, lebih dari itu, yaitu membentuk pikiran, watak, dan perilaku yang baik yang dengan itu anak berhasil. Hal itu sejalan dengan pendapat Thomas Lickona (2005), ia menyatakan bahwa karakter yang baik meliputi memahami, peduli, dan berperilaku berdasarkan nilai-nilai etika dasar.
Pendidikan karakter untuk usia dini disesuaikan dengan perkembangan moral pada anak. Menurut Piaget (1965), perkembangan moral meliputi tiga tahap, yaitu (1) premoral, (2) moral realism, dan (3) moral relativism. Sementara Kolhberg (Power, Higgins, \& Kohlberg, 1989) menyatakan bahwa perkembangan moral mencakup (1) preconventional, (2) conventional, dan (3) postconventional. Esensi kedua teori tersebut sama, yaitu pada tahap awal anak belum mengenal aturan, moral, etika, dan susila. Kemudian, berkembang menjadi individu yang mengenal aturan, moral, etika, dan susila dan bertindak sesuai aturan tersebut. Pada akhirnya, moral, aturan, etika dan susila ada dalam diri setiap anak di mana perilaku ditentukan oleh pertimbangan moral dalam dirinya bukan oleh aturan atau oleh keberadaan orang lain; meskipun tidak ada orang lain, ia malu melakukan hal-hal yang tidak etis, asusila, dan amoral.

Nilai-nilai pendidikan karakter menurut Tim Direktorat Jenderal Pendidikan Anak Usia Dini, Nonformal, dan Informal Kementrian Pendidikan Nasional (2012: 5) dapat ditanamkan pada anak usia dini (0-6 tahun), mencakup empat aspek, yaitu: (1) Aspek Spiritual; (2) Aspek Personal/kepribadian; (3) Aspek Sosial; dan (4) Aspek lingkungan.

Nilai karakter yang dikembangkan oleh kemendiknas tahun 2011 dalam Suyadi (2013) yaitu: (1) Religius; (2) Jujur; (3) Toleransi; (4) Disiplin; (5) Kerja keras; (6) Keratif; (7) Mandiri; (8) Demokratis; (9) Rasa ingin tahu; (10) Semangat kebangsaan atau nasionalisme; (11) Cinta tanah air; (12) Menghargai prestasi; (13) Komunikatif; (14) Cinta damai; (15) Gemar membaca; (16) Peduli lingkungan; (17) Peduli sosial; (18) Tanggung jawab.

Buku cerita bergambar adalah sebuah cerita berbentuk buku dimana 
terdapat gambar sebagai perwakilan cerita yang saling berkaitan. Selain ada gambar dalam buku cerita tersebut juga terdapat tulisan yang mewakili cerita yang ditampilkan oleh gambar diatasnya.

Muh. Nur Mustakim (2005) mengemukakan bahwa buku bergambar adalah buku yang memuat suatu cerita melalui gabungan antara teks dan ilustrasi. Tarigan (1985) mengemukakan bahwa pemilihan gambar haruslah tepat, menarik dan dapat merangsang anak untuk belajar. Media gambar yang menarik, akan menarik perhatian anak dan menjadikan anak memberikan respon awal terhadap proses pembelajaran. Media gambar yang digunakan dalam pembelajaran akan diingat lebih lama oleh anak karena bentuknya yang konkrit dan tidak bersifat abstrak. Gambar adalah suatu bentuk ekspresi komunikasi universal yang dikenal khalayak luas.

Buku bergambar (picture books) menunjuk pada pengertian buku yang menyampaikan pesan lewat dua cara, yaitu lewat ilustrasi dan tulisan (Huck, dkk dalam Nurgiyantoro, (2005). Hal yang tidak berbeda juga dikemukakan Mitchell (Nurgiyantoro, 2005) bahwa buku cerita bergambar adalah buku yang menampilkan gambar dan teks dan keduanya saling menjalin. Baik gambar maupun teks secara mandiri belum cukup untuk mengungkapkan cerita secara lebih mengesankan, dan keduanya saling membutuhkan untuk saling mengisi dan melengkapi. Dengan demikian, pembacaan terhadap buku cerita bacaan tersebut akan terasa lebih lengkap dan konkret jika dilakukan dengan melihat.

Kata-kata dan teks dalam buku cerita bergambar sama pentingnya dengan gambar ilustrasi. Guru akan membantu anak mengembangkan sensitivitas awal ke imajinasi dalam penggunaan bahasa (Huck, dkk dalam Nurgiyantoro, 2005). Bahasa untuk bacaan anak harus sederhana, tetapi tidak perlu penyederhanaan yang berlebihan. Apalagi dalam buku cerita bergambar pemahaman kata-kata itu berada dalam konteks cerita dan yang dapat dipahami bersama dengan bantuan gambar.

Komponen yang harus ada dalam buku cerita bergambar anak ialah gambar dan teks, adapun unsur visal dalam buku cerita bergambar harus diperhatikan oleh penilis buku ceerita bergambar meliputi: (1) warna; (2) efek visual; (3) narasi; (4) tokoh; (5) efek gambar dan teks; dan (6) latar belakang.

\section{METODE}

Bentuk penelitian ini merupakan penelitian pengembangan yang menggunakan metode research and development (R\&D). Produk yang dikembangkan dalam penelitian ini berupa media buku cerita berbasis pendidikan karakter untuk meningkatkan kreativitas AUD. Model yang dipakai dalam pengembangan media ini adalah Model prosedural. Model prosedural adalah Model yang bersifat deskriptif, yaitu menggariskan langkah-langkah yang harus diikuti untuk menghasilkan produk.

Berikut desain pembuatan buku cerita bergambar yang dilakukan oleh peneliti: (1) Menganalisis karakteristik media untuk mengembangkan kreativitas anak; (2) Merumuskan isi buku yang akan di buat (jalan cerita dan ilustrasi); (3) Merancang isi buku cerita yang telah akan di buat (jalan cerita dan ilustrasi); (4) Membuat buku cerita yang telah dirancang; (5) Melakukan validasi isi buku cerita mengenai muatan karakter yang dikembangkan, serta validasi buku cerita bergambar sebagai media pembelajaran bagi anak usia dini; (6) Melakukan uji coba produk. Buku cerita yang telah jadi akan diujuicobakan langsung kepada anak yang 
dibantu oleh guru dalam menggunakan buku tersebut; (7) Evaluate (E). Tujuan utama evaluasi di sini adalah untuk mengetahui keefektifan buku cerita dalam memunculkan semua aspek kreativitas anak.

Teknik analisis data yang digunakan dalam penelitian ini adalah analisis deskriptif kualitatif yaitu dengan mendeskripsikan dan memaknai data yang bersifat kualitatif. Semua data yang bersifat kualitatif akan dianalisis secara kualitatif atau di deskripsikan.

Selain dengan analisis kualitatif, peneliti juga menggunakan teknik analisis kuantitatif untuk menentukan kategorisasi buku cerita yang telah di buat, apakah narasi dan visualisasi yang dibuat dapat di kategorikan kurang, cukup, atau baik serta media buku cerita bergambar ini dapat dikategorikan kurang, cukup, atau baik untuk digunaka anak usia dini. Teknis analisis ini untuk memudahkan peneliti menarik kesimpulan atau mengevaluasi buku cerita bergambar yang dibuat

\section{HASIL DAN PEMBAHASAN \\ Hasil.}

1. Hasil analisis karakteristik media buku cerita bergambar untuk mengembangkan kreativitas anak.

Dalam penelitian ini, untuk mengembangkan buku cerita bergambar yang dapat mengembangkan kreativitas anak, peneliti menggunakan pendapat munandar (1992) mengenai ciri-ciri kreativitas, yaitu: Keterampilan berpikir lancar, Keterampilan berpikir luwes atau fleksibel, Keterampilan berpikir orisinal,
Keterampilan memerinci atau mengelaborasi, Keterampilan menilai. Dalam buku cerita bergambar ini peneliti menuangkan ke lima ciri tersebut dalam keterampilan menggunakan buku cerita yang akan dibuat dalam bentuk langkahlangkah yang dapat digunakan guru dan orang tua, yaitu:

1) Keterampilan berpikir lancar, berupa keterampilan: (a) Dapat memunculkan banyak ide dari setiap halaman / gambar. (b) Dapat memberikan banyak jawaban dari satu pertanyaan terkait dengan gambar / cerita di buku

2) Keterampilan berpikir luwes atau fleksibel, (a) Mampu menceritakan gambar dari berbagai sudut pandang. (b) Mampu mengekspresikan ide dari gambar dengan kalimatnya sendiri. (c) Mampu bercerita tanpa menghiraukan narasi yang tertulis dalam buku namun tetap sesuai gambar

3) Keterampilan berpikir orisinal, (a) Mampu menyampaikan ide yang berbeda atau tidak terduga dan dapat di terima. (b) Dapat mengkombinasikan berbagai ide menjadi satu ide yang baru.

4) Keterampilan memerinci atau mengelaborasi, (a) dapat menambahkan atau memerinci suatu cerita dalam gambar, (b) Keterampilan menilai, (c) dapat memberikan penilaian pada gambar atau cerita yang dibaca

Selain menentukan karakteristik kreativitas di atas, peneliti juga menganalisis karakteristik buku cerita bergambar yang baik yang menggabungkan pendapat Audrey dan Nichols dalam Hidayat (2001) dan Greene \& Petty (dalam Hakim 2001) yaitu:

Tabel 1. Kriteria buku cerita bergambar

\begin{tabular}{lll}
\hline NO & KRITERIA & OPERASIONAL \\
\hline 1 & $\begin{array}{l}\text { Kecermatan } \\
\text { isi }\end{array}$ & $\begin{array}{l}\text { Memuat tentang karakter yang akan dikembangkan dalam } \\
\text { cerita }\end{array}$ \\
\hline 2 & $\begin{array}{l}\text { Ketepatan } \\
\text { cakupan isi }\end{array}$ & $\begin{array}{l}\text { Bentuk-bentuk perilaku apa saja yang akan dimunculkan } \\
\text { dalam buku cerita }\end{array}$ \\
\hline
\end{tabular}




\begin{tabular}{|c|c|c|}
\hline 3 & $\begin{array}{l}\text { Ketercernaan } \\
\text { bahan ajar } \\
\text { dan } \\
\text { pemaparan } \\
\text { yang logis }\end{array}$ & $\begin{array}{ll}\checkmark & \text { Alur cerita runtut } \\
\checkmark & \text { cerita mudah difahami anak }\end{array}$ \\
\hline 4 & $\begin{array}{l}\text { Penggunaan } \\
\text { bahasa }\end{array}$ & $\begin{array}{ll}\checkmark & \text { Kalimat dapat dimengerti anak } \\
\checkmark & \text { Pemilihan kata sesuai untuk anak } \\
\checkmark & \text { Banyak kalimat di setiap halaman sesuai untuk } \\
& \text { bacaan anak } \\
\end{array}$ \\
\hline 5 & Perwajahan & $\begin{array}{ll}\checkmark & \text { Jenis huruf dan ukuran huruf yang digunakan sesuai } \\
& \text { untuk bacaan anak } \\
\checkmark & \text { Posisi gambar dan tulisan seimbang } \\
\checkmark & \text { Petunjuk penggunaan buku jelas } \\
\end{array}$ \\
\hline 6 & Illustrasi & $\begin{array}{ll}\checkmark & \text { Gambar dapat dimengerti anak } \\
\checkmark & \text { Gambar dan warna sesuai untuk bacaan anak } \\
\checkmark & \text { Gambar sesuai dengan pesan / narasi yang di } \\
& \text { tuliskan } \\
\checkmark & \text { Cover yang digunakan menarik } \\
\end{array}$ \\
\hline 7 & $\begin{array}{l}\text { Kelengkapan } \\
\text { komponen }\end{array}$ & $\begin{array}{ll}\text { Buku cerita terdapat unsur: } \\
\checkmark \checkmark \text { Cover } \\
\checkmark & \text { Pengenalan tokoh } \\
\checkmark & \text { Petunjuk penggunaan } \\
\checkmark & \text { Isi cerita } \\
\checkmark & \text { Halaman aktivitas anak } \\
\checkmark & \text { cover belakang }\end{array}$ \\
\hline
\end{tabular}

1. Merumuskan isi buku yang akan di buat (jalan cerita dan ilustrasi)

Buku cerita yang dibuat oleh peneliti harus memuat karakter religius, toleransi, bersahabat, cinta damai, peduli sosial, dan disiplin. Dimana semua karakter ini akan dituangkan dalam bentuk cerita dan ilustrasi yang dapat di terima oleh anak. cerita yang dibuat yaitu mengenai tiga sahabat yang saling peduli satu sama lain. Disini akan disisipkan semua karakter tersebut dalam akivitas mereka dalam keseharian, sehingga menjadi sebuah cerita yang runtut.

2. Hasil rancangan isi buku cerita yang akan di buat (jalan cerita dan ilustrasi)

Tiga tokoh utama dalam cerita adalah anak-anak TK yang memiliki perbedaan karakteristik, baik dari agama dan fisik nya yang berupa warna kulit dan jenis rambut agar mudah untuk di ilustrasikan.

Alur cerita berdasarkan nilai karakter yang ditamankan disusun sedemikian rupa sehingga menghasilkan cerita seperti berikut ini:

Religius : menunjukkan kemauan beribadah dan saling mendoakan kebaikan bagi orang tua dan teman walaupun berbeda agama.

Toleransi: mau berteman dengan teman yang berbeda agama, maupun berbeda secara fisik, dan tidak menghiraukan atau mengejek perbedaan tersebut.

Bersahabat/berkomunikasi : saling peduli, berkomunikasi yang baik dengan teman, menjenguk teman yang sakit, bermain bersama-sama.

Cinta damai : menunjukkan eskpresi gembira saat bersama teman, 
menggunkan kata-kata yang baik saat berbicara, mengucapkan salam saat datang ke rumah teman, berpamitan saat akan pergi.

Peduli sosial : membantu teman seperti mengambilkan air minum, membagi yang dimiliki seperti membagi donat yang di beli kepada teman.

Disiplin : sholat tepat waktu, bergiliran saat bermain tabak.

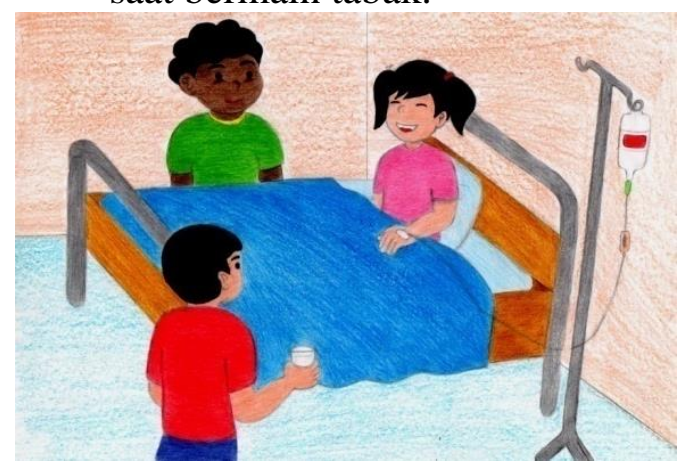

Gambar 1. Karakter Peduli Sosial dan Religius

4. Hasil validasi buku cerita

Peneliti melakukan validasi buku cerita bedasarkan muatan karakter yang terdapat dalam narasi dan gambar pada

Tabel 2. Hasil Validai Muatan

\begin{tabular}{lcc}
\multicolumn{3}{c}{ Karakter } \\
\hline $\begin{array}{l}\text { Karakter yang } \\
\text { dikembangkan }\end{array}$ & $\begin{array}{c}\text { Validator } \\
\mathbf{1}\end{array}$ & $\begin{array}{c}\text { Validator } \\
\mathbf{2}\end{array}$ \\
\hline Religius & 2 & 3 \\
\hline Toleransi & 3 & 2 \\
\hline Bersahabat & 3 & 3 \\
\hline Cinta damai & 3 & 3 \\
\hline Peduli sosial & 2 & 3 \\
\hline Displin & 2 & 3 \\
\hline Total & 15 & 17 \\
\hline Total rata-rata & & 16 \\
\hline
\end{tabular}

3. Membuat buku cerita yang telah dirancang

Setelah alur cerita di buat, peneliti beserta tim ilustrator mulai membuat gambar dari alur yang telah di buat, sehingga jadilah dua puluh gambar, kemudian peneliti menyusun gambar yang telah di buat dan menuliskan narasi untuk memperjelas alur cerita dan pesan karakter yang akan disampaikan.

Berikut beberapa gambar yang memuat karakter yang dirancang.

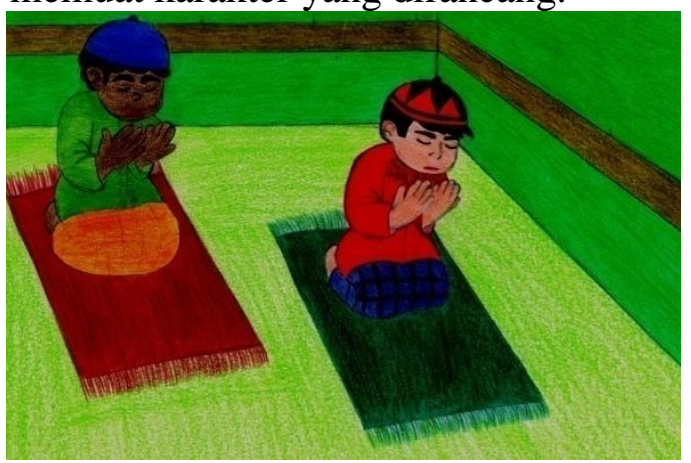

buku cerita, serta melakukan validasi buku cerita bergambar sebagai media pembelajaran bagi anak usia dini.

Kategorisasai, nilai 6 sampai dengan 9 dikategorikan kurang, Nilai 10 sampai dengan 13 dikategorikan cukup. Nilai 14 sampai dengan 18 dikategorikan baik.

Kesimpulan buku cerita bergambar dapat di katakan baik, karena total rataratanya mencapai skor 16, namun demikian perlu ada beberapa perbaikan sesuai saran validator, sehingga peneliti melakukan revisi untuk menyempurnakan buku tersebut, yaitu pada halaman 7 dan 18. Halaman 7 memperbaiki teks yang ada, sedangkan halam 18 memperbaiki gambarnya. 

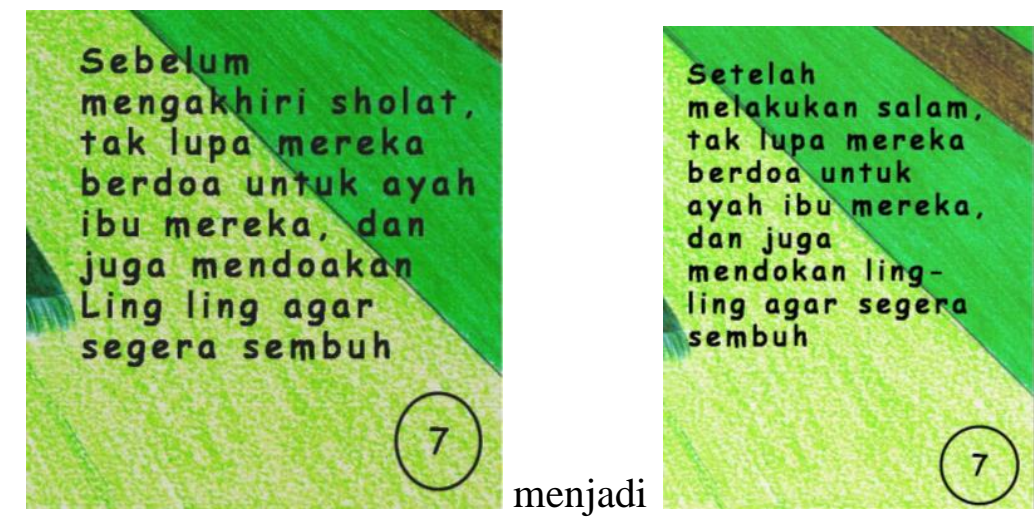

Gambar 2. Perbaikan Teks dalam Gambar
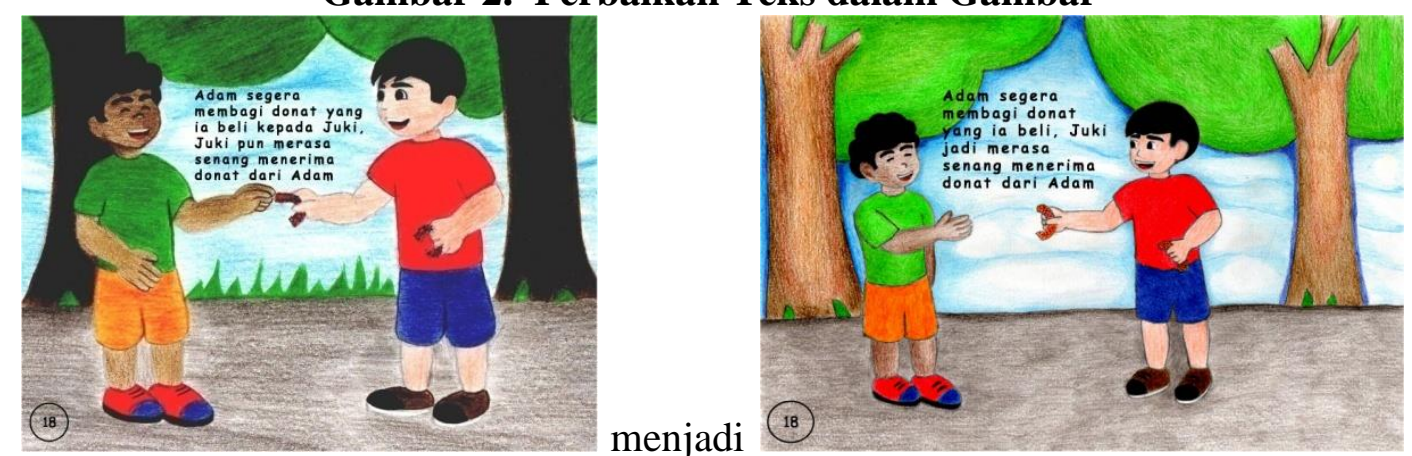

Gambar 3 Perbaikan Ilustrasi

Tabel 3. Hasil validasi media buku cerita bergambar

\begin{tabular}{lcc}
\hline Kriteria buku cerita & Validator 1 & Validator 2 \\
\hline Alur cerita runtut & 3 & 3 \\
\hline cerita mudah difahami anak & 3 & 3 \\
\hline Kalimat dapat dimengerti anak & 3 & 3 \\
\hline Pemilihan kata sesuai untuk anak & 3 & 3 \\
\hline $\begin{array}{l}\text { Banyak kalimat di setiap halaman sesuai untuk bacaan } \\
\text { anak }\end{array}$ & 3 & 3 \\
$\begin{array}{l}\text { Jenis huruf dan ukuran huruf yang digunakan sesuai untuk } \\
\text { bacaan anak }\end{array}$ & 3 & 3 \\
\hline Gambar dapat dimengerti anak & 3 & 3 \\
\hline Gambar dan warna sesuai untuk bacaan anak & 3 & 2 \\
\hline Posisi gambar dan tulisan seimbang & 3 & 3 \\
\hline Gambar sesuai dengan pesan / narasi yang di tuliskan & 3 & 2 \\
\hline Petunjuk penggunaan buku jelas & 3 & 3 \\
\hline Cover yang digunakan menarik & 2 & 3 \\
\hline Total & 35 & 34 \\
\hline Total rata-rata & \multicolumn{2}{c}{34,5} \\
\hline
\end{tabular}

Kategorisasi: Nilai 12 sampai dengan 19,5 dikategorikan kurang, Nilai 19,6 sampai dengan 27,5 dikategorikan cukup, Nilai 27,6 sampai dengan 36 dikategorikan baik.

Maka dapat disimpulkan bahwa buku cerita bergambar yang telah di buat di ketegorikan baik gunakan sebagi media pembelajar untuk anak usia dini. 
5. Hasil Uji coba produk

Tabel 5. 18 Nilai Karakter

\begin{tabular}{clc}
\hline No & \multicolumn{1}{c}{ Kriteria } & $\begin{array}{c}\text { Jumlah anak } \\
\text { yang muncul }\end{array}$ \\
\hline 1 & Dapat memunculkan banyak ide dari setiap halaman / gambar & 14 \\
\hline 2 & $\begin{array}{l}\text { Dapat memberikan banyak jawaban dari satu pertanyaan } \\
\text { terkait dengan gambar / cerita di buku }\end{array}$ & 13 \\
\hline 3 & Mampu menceritakan gambar dari berbagai sudut pandang & 13 \\
\hline 4 & $\begin{array}{l}\text { Mampu mengekspresikan ide dari gambar dengan kalimatnya } \\
\text { sendiri }\end{array}$ & 13 \\
\hline 5 & $\begin{array}{l}\text { Mampu bercerita tanpa menghiraukan narasi yang tertulis } \\
\text { dalam buku namun tetap sesuai gambar }\end{array}$ & 12 \\
\hline 6 & $\begin{array}{l}\text { Mampu menyampaikan ide yang berbeda atau tidak terduga } \\
\text { dan dapat di terima }\end{array}$ & 13 \\
\hline 7 & $\begin{array}{l}\text { Dapat mengkombinasikan berbagai ide menjadi satu ide yang } \\
\text { baru }\end{array}$ & $\begin{array}{l}\text { Dapat menambahkan atau memerinci suatu cerita dalam } \\
\text { gambar }\end{array}$ \\
\hline 9 & $\begin{array}{l}\text { Dapat memberikan penilaian pada gambar atau cerita yang } \\
\text { dibaca }\end{array}$ & 2 \\
\hline
\end{tabular}

Dari data hasil observasi di atas, dapat disimpulkan bahwa semua ciri kreativitas dapat dimunculkan melalui penggunaan buku cerita bergambar yang dibuat oleh peneliti.

6. Hasil evaluasi (E). Tujuan utama evaluasi di sini adalah untuk mengetahui keefektifan buku cerita dalam memunculkan semua aspek kreativitas anak.

Berdasarkan data observasi mengenai ciri dari kreativitas anak ketika belajar menggunakan buku cerita bergambar yang dibuat oleh peneliti, semua ciri kreativitas dapat dimunculkan, namun untuk mengoptimalkan fungsi dari buku ini, peran guru dan orang tua sangat besar yaitu harus mengikuti atau melakukan semua petunjuk penggunaan buku, dengan kata lain, buku akan lebih efektif jika digunakan anak bersama dengan pendidik baik itu guru maupun orang tua.

\section{Pembahasan}

Setelah peneliti melakukan prosedur langkah-langkah pembuatan buku cerita bergambar untuk anak. Didapatkan hasil yang baik, secara umum buku cerita bergambar yang dibuat oleh peneliti telah memunculkan nilai karakter yang baik bagi anak dan dapat memunculkan lima ciri berfikir kreatif.

Kementrian pendidikan nasional mulai tahun 2011 telah menetapkan 18 nilai karakter yang di harus ditanamkan pada anak, yaitu religius, jujur, toleransi, disiplin, kerja keras, kreatif, mandiri, demokratis, rasa ingin tahu, nasionalis, cinta tanah air, menghargai prestasi, komunikatif, cinta damai, gemar membaca, peduli lingkungan, peduli sosial, dan tanggung jawab.

Berdasarkan hasil validasi yang telah dilakukan, buku cerita bergambar yang dikembangkan oleh peneliti memuat beberapa nilai karakter di atas, yaitu religius, toleransi, bersahabat, cinta damai, peduli sosial, dan disiplin. Karakter- 
karakter tersebut disampaikan melalui alur cerita yang dibuat. Selain karakter yang dimunculkan dalam alur cerita, peneliti juga melatihkan karakter kreatif pada anak melalui kegiatan yang dilakukan menggunakan buku cerita yang dibuat peneliti yang disampaikan melalui petunjuk penggunaan buku.

Sesuai dengan pendapat munandar (1992) bahwa ciri kreativitas yang terkait dengan kemampuan berfikir yaitu memiliki ciri mampu befikir lancar, luwes, original, elaboratif, dan evaluatif. Oleh sebab itu peneliti menyusun petunjuk penggunaan buku berdasarkan kelima ciri di atas. Setelah melakukan uji coba secara klasikal di kelompok anak TK B, ternyata semua ciri tersebut berhasil dimunculkan oleh anak. Walau tidak setiap anak memunculkan semua ciri kreativitas tersebut, karena kemunculan ciri kreativitas tersebut sangat bergantung dari kreativitas anak masing-masing. Namun dengan mengikuti petunjuk penggunaan yang telah peneliti sisipkan dalam buku cerita bergambar, kelima kemampuan

DAFTAR RUJUKAN

Ain, F.A. 2011. Patiseri jilid 2. Jakarta: direktorat pembinaan sekolah kejuruan.

DeRoche, Edward. 2009. The What, Why, and How of Character Education. http://www.csee.org/products/ 108 Kementerian Pendidikan Nasional, dalam Suyadi. 2013. Strategi Pemebelajaran Pendidikan Karakter. Bandung: Remaja Rosdakarya

Lickona, T. \& Matthew Davidson. 2005. Smart \& good high schools: Integrating excellence and ethics for success in school, work, and beyond. Cortland, NY: The Character Education Partnership. tersebut dapat di asah dan dikembangkan oleh guru maupun orang tua.

\section{KESIMPULAN DAN SARAN Kesimpulan}

Buku cerita bergambar yang dibuat peneliti telah memuat nilai karakter religius, toleransi, bersahabat, cinta damai, peduli sosial, dan disiplin, selain itu dengan mengikuti petunjuk penggunaan buku, maka ciri kreativitas seperti kemampuan berfikir lancar, luwes, original, elaboratif, dan evaluatif dapat dimunculkan pada anak.

\section{Saran}

Walau tidak setiap anak memunculkan semua ciri kreativitas tersebut, karena kemunculan ciri kreativitas tersebut sangat bergantung dari kreativitas anak masing-masing. Namun dengan mengikuti petunjuk penggunaan yang telah peneliti sisipkan dalam buku cerita bergambar, kelima kemampuan tersebut dapat di asah dan dikembangkan oleh guru maupun orang tua.

www.cortland.edu/character/hi

ghschool.

Muh. Nur Mustakim. (2005). Peranan Cerita Pembentukan Perkembangan Anak TK. Jakarta: Depdiknas.

Nurgiyantoro, Burhan. (2005). Sastra Anak. Yogyakarta: Gadjah Mada University Press..

Sadiman. 2012. Media pendidikan (pengertian, pengembangaan, dan pemanfaatannya. Jakarta: Grafindo Persada

Sugiono. 2011. Metode penelitian pendidikan (pendekatan kualitatif, kuantitatif, dan R\&D). Bandung : alfabeta.

Tarigan. (1985). Prinsip-prinsip Dasar Sastra. Bandung: Angkasa. 
Piaget, Jean. 1965. The Moral Judgment of The Child. New York: The Free Press.
Power, F. C.; Higgins, A., \& Kohlberg, L. 1989. Lawrence Kohlberg's Approach to Moral Education. New York: Columbia University Press. 